\title{
Avaliação da eficácia de desinfetantes comerciais no piso de chão batido em galpões de aves matrizes de corte*
}

\author{
FERNANDO PILOTTO
}

\author{
Vladimir Pinheiro do Nascimento (Orientador - UFRGS) \\ Vilson Antônio Klein (Co-orientador - UPF)
}

Banca: Maristela Lovato Flores (UFSM), Marisa da Costa (UFRGS), José Maria Wiest (UFRGS)

O piso de chão batido é utilizado na maioria das granjas avícolas brasileiras devido ao alto custo da construção de pisos concretados. A presença de matéria orgânica na superfície do solo dificulta sua desinfecção, devido à redução da ação antimicrobiana dos desinfetantes. Os testes realizados in vitro para verificar a eficácia dos desinfetantes não contemplam as condições adversas encontradas em granjas avícolas. Assim, avaliações a campo podem ser consideradas mais seguras por demonstrarem a real ação antimicrobiana dos produtos utilizados. O presente trabalho teve o intuito de determinar o melhor desinfetante para ser empregado na desinfecção de chão batido. Para tanto, necessitou inicialmente definir o volume de solução desinfetante a ser utilizado por $\mathrm{m}^{2}$ de piso através da contagem de coliformes totais e fecais em profundidade e da análise físico-hídrica do solo. Foi detectada a presença de coliformes totais e fecais na profundidade de $0,5 \mathrm{~cm}$, e o volume de solução desinfetante definida para saturar $1 \mathrm{~m}^{2} \mathrm{a}$ $1 \mathrm{~cm}$ de profundidade, considerando a presença de rachaduras, foi de 01 litro. Após, testou-se seis desinfetantes comerciais (soda cáustica, cal hidratada, fenol 1 , fenol 2, iodo e amônia quaternária com glutaraldeído), utilizando-se a água da diluição como controle, em piso de chão batido. Para o delineamento experimental foram utilizados blocos casualizados, com três repetições. A ação dos produtos foi verificada a campo pela redução do número presuntivo de coliformes, coliformes totais e fecais, através do uso da técnica do número mais provável (NMP). As amostras de Escherichia coli isoladas antes e após a aplicação dos desinfetantes foram utilizadas para avaliar a eficácia dos desinfetantes pela técnica in vitro. A análise estatística dos dados foi realizada através da Análise de Variância e do Teste Tukey. Na contagem presuntiva de coliformes, dos seis desinfetantes testados, a cal hidratada foi a que apresentou a melhor eficácia, reduzindo em média 2,9 log da contaminação inicial. Os níveis de redução de coliformes totais da cal hidratada foram melhores que os obtidos pela soda cáustica, fenol 1, iodo, composto a base de amônia quaternária com glutaraldeído e controle, enquanto que o fenol 2 foi mais eficaz que o iodo $(\mathrm{p}=0,0001)$. Quanto à ação sobre os coliformes fecais, a cal hidratada foi a que obteve os maiores níveis de redução, apresentando diferença em relação ao iodo, amônia quaternária com glutaraldeído e controle ( $\mathrm{p}=0,0001$ ). Os desinfetantes que obtiveram os maiores níveis de redução de coliformes fecais pela técnica do NMP, também foram eficazes quando testados frente a amostras de Escherichia coli pela técnica de avaliação de desinfetantes in vitro. Entretanto, os mesmos desinfetantes apresentaram resultados distintos na redução de coliformes totais e número presuntivo de coliformes. Pelos dados obtidos observou-se que a ação antibacteriana de um desinfetante pode estar associada à presença de matéria orgânica na superfície onde será aplicado e à flora bacteriana a qual será submetido. Dentre os desinfetantes testados, a cal hidratada foi o produto que obteve os melhores resultados na redução do número presuntivo de coliformes, coliformes totais e coliformes fecais no piso de chão batido de granjas avícolas. A cal hidratada foi o desinfetante que apresentou o melhor custo/benefício entre os produtos testados $\left(\mathrm{R} \$ 0,044 / \mathrm{m}^{2}\right)$.

Descritores: chão batido, desinfetantes, coliformes. 


\title{
Efficacy comparison of commercial disinfectants on clod soil used as floor in poultry breeder houses*
}

\author{
FERNANDO PILOTTO
}

\author{
Vladimir Pinheiro do Nascimento (Adviser - UFRGS) \\ Vilson Antônio Klein (Co-Adviser - UPF)
}

Committee: Maristela Lovato Flores (UFSM), Marisa da Costa (UFRGS), José Maria Wiest (UFRGS)

The clod soil ground is used in most of the Brazilian poultry farms due to the high cost of the construction of concreted floors. The presence of organic matter on the surface of the soil hinders its disinfection, due to the reduction of the antimicrobial action of disinfectants. The tests accomplished 'in vitro' to verify the effectiveness of the disinfectants do not contemplate the adverse conditions found at poultry farms. Thus, evaluations on field can be considered safer for demonstrating the real antimicrobial action of the used products. The present work intended to determinate the best disinfectant to be used in the disinfection of clod soil ground. To do so, it was first needed to define the volume of disinfectant solution to be used on $\mathrm{m}^{2}$ floor, through the counting of total and fecal coliforms in depth and also the soil's physical-hydric analysis. Presence of total and fecal coliforms was detected in the depth of $0,5 \mathrm{~cm}$ and the volume of disinfectant solution defined to saturate $1 \mathrm{~m}^{2}$ to $1 \mathrm{~cm}$ of depth was of 1 liters. After that, six commercial disinfectants (caustic sodium, moisturized whitewash, phenol 1, phenol 2, I iodize, glutaraldeide and quaternary ammonia) were tested, while dilution water was used as control, the clod soil. Delineate random blocks, with three repetitions were used in the experiment. The action of the products was verified at field by the reduction of the presumed coliforms, total and fecal coliforms through the technique of the most probable number (MPN). The samples of Escherichia coli isolated before and after the application of the disinfectants were used to evaluate the efficiency of the disinfectants use of "in vitro". The statistical analysis of the data was accomplished through the Analysis of Variance and the Tukey's Test. In the coliforms presumed counting among, of the six tested disinfectants, the moisturized whitewash $\left(\mathrm{Ca}(\mathrm{OH})_{2}\right)$ was the one which presented the best effectiveness, reducing adaverage of 2,9 log of the initial contamination. The levels of reduction of total coliforms of the moisturized whitewash were better than those obtained by the caustic sodium, phenol 1, Iodize, quaternary ammonia whit glutaraldeide and control, while the phenol 2 was more effective than the iodine and the control ( $\mathrm{p}=0,0001)$. Regarding the reduction of fecal coliforms, the moisturized whitewash obtained the highest reduction levels, presenting a difference when compared to the iodine, quaternary ammonia with glutaraldeide and control ( $\mathrm{p}=0,0001)$. The disinfectants that obtained the largest levels of reduction of fecal coliforms by the MPN technique were also effective when tested against samples of Escherichia coli by the "in vitro" disinfectant evaluation technique. However, the same disinfectants presented different results regarding the reduction of total coliforms and presumed coliforms numbes. Based on the obtained data, it could be observed that the antibacterial action of a disinfectant is associated to the presence of organic matter on the surface where it will be applied and also to the bacterial flora against which it that will be submitted. Among the tested disinfectants, the moisturized whitewash was the product that obtained the best results in reducing of the number of presumptive coliforms, total coliforms and fecal coliforms on the grounds of clod soil at poultry farms. The moisturized whitewash was the product which presented the best cost/benefit relation among on the disinfectants tested $\left(\mathrm{US} \$ 0,015 / \mathrm{m}^{2}\right)$.

Key words: clod soil, disinfectants, coliforms. 